\title{
Prioritization of Stakeholders in Diffusion of CAU-R Series Varieties in Manipur
}

\author{
Jyothi S.S.P ${ }^{1}$, Loukham Devarani ${ }^{1 *}$, K. Noren Singh ${ }^{1}$, Ram Singh ${ }^{1}$, Rajkumar Josmee \\ Singh $^{1}$, L. Hemochandra ${ }^{1}$, M. Kunjaraj Singh ${ }^{2}$ and Daya Ram ${ }^{2}$
}

${ }^{1}$ College of Post Graduate Studies in Agricultural Sciences, Central Agricultural University (Imphal), School of Social Sciences, 793103 - Umiam, Meghalaya, India

${ }^{2}$ College of Agriculture, Central Agricultural University (Imphal), Department of Extension Education, 795004 - Iroisemba, Manipur, India

*Corresponding author: loukham.d@gmail.com

\begin{abstract}
This study was conducted in order to understand the importance of the identified stakeholders in terms of power and interest in the diffusion of CAU-R series high yielding varieties of Rice among the farmers of Manipur. Three valley districts namely Imphal East, Thoubal and Bishnupur were purposively selected for the study and 85 stakeholders were identified and prioritised according to "degree of power to" and "degree of interest on" in the successful dissemination of improved technology among the farming fraternity. The results of the study witnessed that the Central Agricultural University, Imphal, the Department of Agriculture, Manipur and the Ministry of Agriculture and Farmers Welfare had high power and high interest in all the three districts along with Krishi Vigyan Kendra Imphal East, Krishi Vigyan Kendra Thoubal and the Regional Rice Research Station in Imphal East and Thoubal districts respectively. The farmers and the Farmer collectives were identified with high interest and low power while the Indian Council of Agricultural Research, Regional Centre, Manipur and Krishi Vigyan Kendra, Imphal West remained with neutral power and interest in all the three districts. The Media comprising mainly of the All India Radio, Doordarshan Television and the local newspaper Sangai express has very low interest as well as power in all the three districts. Through these observations we conclude that stakeholders like farmers and farmer cooperatives who are the actual intenders of the technology with considerable level of interest should be involved into the system for effective planning, decision-making and successful functioning of the innovation system.

\section{Highlights}

( The public organizations dominated the stakeholder typology and the CAU had the ultimate power of decision-making and resource allocation.

( The CAU, SDA, MoA\&F, KVK-A, KVK-TH \& RRS had high interest and power while the farmers and their collectives had high interest and low power.
\end{abstract}

Keywords: Stakeholder, Diffusion, Improved Technology, Rice, Manipur

The process of diffusion and adoption of any new technology requires the collaborative effort of multiple stakeholders (Badibanga et al. 2013). A stakeholder is any individual with a blatant or credible interest or stake in a policy issue. Stakeholders may assume any form, size and capacity (ODA, 1995). They can be individuals, organizations, or unorganized groups. Stakeholder
Analysis (SA) is an approach to expedite institutional and policy transformation processes by being responsible for and regularly integrating the needs of those who have a 'stake' or an interest in the reforms under consideration (MacArthur, 1997). According to Dentoni and Peterson (2011), multistakeholder engagement in agri-food supply chain has become very essential to make agricultural 
research globally competitive power by 2020 . Considerable higher percent of the smallholder farmers in developing countries are threatened with challenges diverse in nature and to overcome them an integrated approach of multi-stakeholder involvement responsive to the farming needs is required (Martey et al. 2014).

Rice is the major important cereal cultivated in India since ages. It is assumed that the foothills of Eastern Himalayas i.e. North-Eastern Region (NER) of India were the place where first the indica variety of rice was domesticated. India has about 705 varieties of Rice cultivated (Thongbam et al. 2010). The NER comprises 7.9 per cent area under cultivation of the country and 6.23 per cent of total production (Annual Report, MoA\&F, GoI, 2017).

Rice cultivation in Manipur, which is one of the most fertile sub-tropical rain-fed farming zones of Asia, is as old as 6,000 years. Geographically, the state is gifted with enormous natural resources and rice germplasm (Medhabati et al. 2013). However, only 7.41 per cent of the total geographical area of the state is used for cultivation of which 52.00 per cent is limited to the valley. 67per cent of the total population of the state resides in half of the total valley region and is engaged for agriculture activities. In order to feed this percent of populace there is a high pressure on land in the valley (GoM, 2015). Population has increased by 12.05 per cent during 2001-2011, whereas the state has registered negative annual growth (-0.48 per cent) in the case of area under rice during 2000-01 to 2011-12 (Singh et al. 2016). There is no scope of increasing the area under valley districts and therefore it is essential to increase the production of rice to feed the rapidly growing population. Introduction and adoption of High Yielding Varieties (HYVs) which are suitable to the prevailing agro-ecological situation of the region is one of the solutions to this problem.

The Central Agricultural University, Imphal has developed a series of CAU High yielding Rice varieties under the name CAU-R varieties viz., CAU-R1 (Tamphaphou), CAU-R2 (Maniphou), CAU-R3 (Mangalphou) and CAU-R4 (Eenotphou). The CAU-R1 is a cross between Leimaphou and BR1. It is a short duration crop of 125-130 days duration adapted to rainfed wetland fields of Manipur valley. The variety is known for its high yield of 5-6 tons/ha compared to other high yielding varieties of rice and resistant to blast bacterial leaf blight and rice gall midge. The variety was released in 1999 and notified in 2009 and is a promising variety to boost the production and productivity of rice in Manipur. The highest yield of CAU-R1 was recorded as 8.8t/ha during kharif 2009 and 12.3t/ ha during kharif 2014-15 by farmers who secured awards during crop competitions conducted by the Department of Agriculture, Government of Manipur (CAU Farm Magazine, Vol 7, No.4). The variety has been disseminated to the farmers of North Eastern States specifically Manipur for testing their acceptance and adoption and was reported that significantly large number of farmers in the valley districts of Manipur have adopted the variety with high level of satisfaction.

The need of more convergence among the various stakeholders involved in the production of the food systems have led to a number of recent studies in agricultural sciences related to stakeholders. The objective of the study was to identify and analyse the important stakeholders involved in diffusion of the CAU-R series more specifically CAU-R1.

\section{MATERIALS AND METHODS}

\section{Research Design}

The research design employed for the study was a descriptive and inferential research design which implies to observe and understand who, what, how and why of the system.

\section{Sampling method}

The sampling method used was purposive sampling and snowball sampling method to identify the stakeholders.

\section{Method of data collection}

Data was collected using a pre-tested structured interview schedule as primary tool and group discussions and key informant technique as secondary tool when required. The respondents were selected based on complete enumeration technique. The total numbers of respondents were 19 institutional stakeholders and 66 farmer stakeholders, totalling to 85 . The data presented in this study pertains to three valley districts viz, Thoubal, Imphal East and Bishnupur where there 
is more concentration of CAU R1 rice growers. The stakeholders were plotted on the 'power to' and 'interest in' map by taking the mean score of the key personnel from the CAU, Imphal involved in the diffusion of CAU-R series on a 10 point continuum. Based on the mean scores the stakeholders are categorised into four categories as High Power-High Interest, High Power- Low Interest, Low Power-Low Interest, Low Power-High Interest respectively.

\section{RESULTS AND DISCUSSION}

\section{(I) Stakeholder Identification}

The important stakeholders of the CAU-R series varieties were identified through the concerned authority of the Central Agricultural University, Imphal. Thereafter, other stakeholders were identified through snowball sampling technique from the earlier identified ones. Institutional stakeholders were 19 including public/ government organizations, media and non-governmental organizations. Farmer stakeholders included the farmers who actually understood who a stakeholder is and responded properly numbering to 66 from the three districts. According to Russo and Tencati (2009) stakeholders come in various forms such as formal, informal and differing sizes. Barzola et al. (2019) recognized "typologies" as the group of stakeholders similar to one another in governance mechanisms and type of innovations. In this study, typology of stakeholders implies the governing agency and governance mechanism. A brief description of the identified stakeholders in terms of their typology, description, their roles and possible impact on the diffusion of the CAU-R varieties is explained in Table 1. It was observed that majority of the stakeholders identified are Public sector/ Government organisations The other category of stakeholders is the media, the farmer collectives and the civil society organizations. The stakeholders under the public domain governed by the public authorities are classified into sub-categories based on the nature of activities carried out as Policy makers, Academic Institutes, Research Institutes and Extension organizations.

\section{Policy Makers}

The Ministry of Agriculture and Farmers Welfare, Government of India and the Department of Agriculture, Government of Manipur constitute the policy makers. The Academic institutes include those institutes or organizations whose primary objective was imparting education while secondary objective was conducting research and extension

Table 1: Stakeholder in the diffusion of CAU-R varieties

\begin{tabular}{|c|c|c|c|c|c|}
\hline $\begin{array}{l}\text { S1. } \\
\text { No. }\end{array}$ & Stakeholder & Description & Role & Interest in the initiative & $\begin{array}{l}\text { Likely impact } \\
\text { of initiative on } \\
\text { interest }\end{array}$ \\
\hline & \multirow{3}{*}{$\begin{array}{l}\text { Ministry of Agriculture } \\
\text { and Farmers Welfare, } \\
\text { Govt. of India }\end{array}$} & \multirow{3}{*}{$\begin{array}{l}\text { It is an apex body for all } \\
\text { policy related issues regarding } \\
\text { agriculture and farmers welfare } \\
\text { in the country }\end{array}$} & \multirow{3}{*}{$\begin{array}{l}\text { - Policy formulation and } \\
\text { Implementation } \\
\text { - Funding } \\
\text { - Facilitator } \\
\text { - M\&E }\end{array}$} & Increased crop production & $(+)$ \\
\hline & & & & Sustainable Agriculture & $(+)$ \\
\hline & & & & Livelihood of the farmers & $(+)$ \\
\hline & \multirow{3}{*}{$\begin{array}{l}\text { Department of } \\
\text { Agriculture, Govt of } \\
\text { Manipur }\end{array}$} & \multirow{3}{*}{$\begin{array}{l}\text { Responsible for all the } \\
\text { agricultural activities in the } \\
\text { state. Certified seed production } \\
\text { by the state seed certification } \\
\text { agencies and the National Seed } \\
\text { Corporation. Conducts annual } \\
\text { crop competitions and awards } \\
\text { farmers with highest yield. This } \\
\text { motivates the farmers to adopt } \\
\text { HYVs. }\end{array}$} & \multirow{3}{*}{$\begin{array}{l}\text { - Policy formulation \& } \\
\text { implementation } \\
\text { - Research } \\
\text { - M\&E, } \\
\text { - Funding } \\
\text { - Input Supplier } \\
\text { - ToT, } \\
\text { - Publicity } \\
\text { - Facilitator and } \\
\text { - Coordinator } \\
\text { - Market linkages }\end{array}$} & $\begin{array}{l}\text { Promote use of HYVs across } \\
\text { the state }\end{array}$ & $(+)$ \\
\hline & & & & Transfer of technology & $(+)$ \\
\hline & & & & Policy Implication & $(+)$ \\
\hline
\end{tabular}




\begin{tabular}{|c|c|c|c|c|}
\hline \multirow{6}{*}{$\begin{array}{l}\text { Central Agricultural } \\
\text { University, Imphal }\end{array}$} & \multirow{6}{*}{$\begin{array}{l}\text { Premier academic institute } \\
\text { involved in agricultural } \\
\text { education, research and } \\
\text { extension in the north eastern } \\
\text { hill region of the country. } \\
\text { CAU-R series were developed } \\
\text { by scientists of CAU and the } \\
\text { university has a key role in } \\
\text { popularising the varieties } \\
\text { among the farmers of the region }\end{array}$} & \multirow{6}{*}{$\begin{array}{l}\text { - Policy formulation \& } \\
\text { implementation, } \\
\text { - Research, } \\
\text { - Developer, } \\
\text { - M\&E, } \\
\text { - Funding, } \\
\text { - Input Supplier, } \\
\text { - ToT, } \\
\text { - Publicity, } \\
\text { - Facilitator and } \\
\text { Coordinator, } \\
\text { - Market linkages }\end{array}$} & University Mandate & $(+)$ \\
\hline & & & $\begin{array}{l}\text { Increased production and } \\
\text { productivity of the region }\end{array}$ & $(+)$ \\
\hline & & & Recognition\&Awards & $(+)$ \\
\hline & & & Livelihood of the farmers & $(+)$ \\
\hline & & & Sustainable Agriculture & $(+)$ \\
\hline & & & $\begin{array}{l}\text { Combating effect of climate } \\
\text { change on Rice }\end{array}$ & $(+)$ \\
\hline \multirow{4}{*}{$\begin{array}{l}\text { Pandit Deen Dayal } \\
\text { Upadhyay Institute of } \\
\text { Agriculture Sciences, } \\
\text { Bishnupur }\end{array}$} & \multirow{4}{*}{$\begin{array}{l}\text { The primary objective is to } \\
\text { impart agricultural education } \\
\text { at Graduation and Post- } \\
\text { Graduation level. }\end{array}$} & \multirow{4}{*}{$\begin{array}{l}\text { Transfer of Technology, } \\
\text { Facilitator and } \\
\text { Coordinator }\end{array}$} & Livelihood of the farmers & $(+)$ \\
\hline & & & \begin{tabular}{|l|} 
Transfer of Technology \\
\end{tabular} & $(+)$ \\
\hline & & & $\begin{array}{l}\text { Better inter-organization } \\
\text { relation }\end{array}$ & $(+)$ \\
\hline & & & Sustainable Agriculture & $(+/ 0)$ \\
\hline \multirow{5}{*}{$\begin{array}{l}\text { Indian Council of } \\
\text { Agricultural Research, } \\
\text { RC-Manipur }\end{array}$} & \multirow{5}{*}{$\begin{array}{l}\text { Coordinating and conducting } \\
\text { region specific research in } \\
\text { Manipur }\end{array}$} & \multirow{5}{*}{$\begin{array}{l}\text { No role specific to } \\
\text { CAU-R series varieties } \\
\text { as the organization has } \\
\text { developed their own } \\
\text { HYVs in Rice known } \\
\text { as RCM series and } \\
\text { popularization of these } \\
\text { is their primary goal. }\end{array}$} & $\begin{array}{l}\text { Promotion of HYVs released by } \\
\text { ICAR }\end{array}$ & $(-)$ \\
\hline & & & Livelihood of farmers & $(+)$ \\
\hline & & & Increased Yield & $(+)$ \\
\hline & & & Organization mandate & $(-)$ \\
\hline & & & Recognition and Rewards & $(-)$ \\
\hline \multirow{4}{*}{$\begin{array}{l}\text { Rice Research Station, } \\
\text { Wangbal, Thoubal }\end{array}$} & \multirow{4}{*}{$\begin{array}{l}\text { The primary objective is } \\
\text { conducting experiments } \\
\text { and research, demonstration } \\
\text { of improved techniques } \\
\text { of cultivation of rice and } \\
\text { multiplication of improved and } \\
\text { high yielding varieties of the } \\
\text { crop. }\end{array}$} & \multirow{4}{*}{$\begin{array}{l}\text { - Research, } \\
\text { - Transfer of Technology, } \\
\text { Facilitator and } \\
\text { Coordinator }\end{array}$} & Improved research on rice & $(+)$ \\
\hline & & & Develop new varieties & $(+)$ \\
\hline & & & Transfer of technology & $(+/ 0)$ \\
\hline & & & Recognition & $(+)$ \\
\hline \multirow[t]{5}{*}{ KVK Thoubal } & \multirow{5}{*}{$\begin{array}{l}\text { The only KVK in the state } \\
\text { hosted by the Department of } \\
\text { Agriculture, Manipur. It was } \\
\text { sanctioned by the ICAR in } \\
\text { the year 2005. Active role in } \\
\text { popularization and diffusion } \\
\text { of CAU-R series varieties in } \\
\text { Thoubal district. }\end{array}$} & \multirow{5}{*}{$\begin{array}{l}\text { - Input suppliers, } \\
\text { - Research, } \\
\text { - Transfer of } \\
\text { Technology, Facilitator, } \\
\text { Coordinator }\end{array}$} & Transfer of technology & $(+)$ \\
\hline & & & Organization mandate & $(+)$ \\
\hline & & & Livelihood of farmers & $(+)$ \\
\hline & & & Trainings & $(+)$ \\
\hline & & & Capacity Building & $(+)$ \\
\hline \multirow[t]{5}{*}{ KVK Imphal East } & \multirow{5}{*}{$\begin{array}{l}\text { This KVK is hosted by the KVK } \\
\text { hosted by the Central Agricul- } \\
\text { tural University, Imphal. It was } \\
\text { sanctioned by the ICAR in the } \\
\text { year } 2005 \text {. The primary objective } \\
\text { is to transfer technology and } \\
\text { conduct vocational trainings to } \\
\text { the farmers. Key player among } \\
\text { the KVKs in popularization and } \\
\text { diffusion of CAU-R series vari- } \\
\text { eties in Imphal East district. }\end{array}$} & \multirow{5}{*}{$\begin{array}{l}\text { - Developer, } \\
\text { - Input suppliers, } \\
\text { - Research, } \\
\text { - Transfer of Technology, } \\
\text { Facilitator and } \\
\text { Coordinator }\end{array}$} & Transfer of technology & $(+)$ \\
\hline & & & Organization mandate & $(+)$ \\
\hline & & & Livelihood of farmers & $(+)$ \\
\hline & & & Trainings & $(+)$ \\
\hline & & & Capacity Building & $(+)$ \\
\hline \multirow[t]{4}{*}{ KVK Bishnupur } & \multirow{4}{*}{$\begin{array}{l}\text { This KVK, sanctioned in } 2003 \text { is } \\
\text { hosted by the NGO Utlou Co-op } \\
\text { Society Limited. }\end{array}$} & \multirow{4}{*}{$\begin{array}{l}\text { - Input suppliers, } \\
\text { - Research, } \\
\text { - Transfer of Technology, } \\
\text { Facilitator and } \\
\text { Coordinator }\end{array}$} & Transfer of technology & $(+)$ \\
\hline & & & Livelihood of farmers & $(+)$ \\
\hline & & & Trainings & $(+)$ \\
\hline & & & Capacity building & $(+)$ \\
\hline
\end{tabular}




\begin{tabular}{|c|c|c|c|c|}
\hline \multirow{4}{*}{ KVK Imphal West } & \multirow{4}{*}{$\begin{array}{l}\text { It is the oldest KVK in the } \\
\text { state sanctioned in } 1979 \text {. It is } \\
\text { hosted by the ICAR-NEH, RC } \\
\text { Manipur The primary objective } \\
\text { is to transfer technology and } \\
\text { conduct vocational trainings to } \\
\text { the farmers. }\end{array}$} & \multirow{4}{*}{$\begin{array}{l}\text { No role specific to } \\
\text { CAU-R series varieties }\end{array}$} & Transfer of technology & $(+)$ \\
\hline & & & Livelihood of farmers & $(+)$ \\
\hline & & & $\begin{array}{l}\text { Popularization of ICAR released } \\
\text { HYVs }\end{array}$ & $(-)$ \\
\hline & & & Recognition and Rewards & $(-)$ \\
\hline \multirow[t]{3}{*}{ All India Radio } & \multirow{3}{*}{$\begin{array}{l}\text { They serve as means of } \\
\text { communication between the } \\
\text { scientific community and the } \\
\text { farming fraternity }\end{array}$} & \multirow{3}{*}{$\begin{array}{l}\text { Publicity, } \\
\text { Facilitator and } \\
\text { communication } \\
\text { channels between } \\
\text { farmers and other } \\
\text { stakeholders }\end{array}$} & Promotional activities & $(+/ 0)$ \\
\hline & & & Facilitate technical support & $(+/ 0)$ \\
\hline & & & Provide Market information & $(+/ 0)$ \\
\hline \multirow[t]{4}{*}{$\begin{array}{l}\text { Television } \\
\text { (DoordarshanKisan) }\end{array}$} & \multirow{4}{*}{$\begin{array}{l}\text { They serve as means of } \\
\text { communication between the } \\
\text { scientific community and the } \\
\text { farming fraternity }\end{array}$} & \multirow{4}{*}{$\begin{array}{l}\text { Publicity, } \\
\text { facilitator and } \\
\text { communication } \\
\text { channels between } \\
\text { farmers and other } \\
\text { stakeholders }\end{array}$} & $\begin{array}{l}\text { Video Broadcast of agricultural } \\
\text { technologies }\end{array}$ & $(+/ 0)$ \\
\hline & & & Aid in Skill enhancement & $(+/ 0)$ \\
\hline & & & $\begin{array}{l}\text { Generate interest in adopting } \\
\text { new HYVs }\end{array}$ & $(+/ 0)$ \\
\hline & & & $\begin{array}{l}\text { Feedback coordination between } \\
\text { farmers and stakeholders }\end{array}$ & $(+/ 0)$ \\
\hline \multirow{2}{*}{$\begin{array}{l}\text { Newspaper (Sangai } \\
\text { Express) }\end{array}$} & \multirow{2}{*}{$\begin{array}{l}\text { Local newspaper widely } \\
\text { circulated in the state }\end{array}$} & \multirow{2}{*}{$\begin{array}{l}\text { Publicity and } \\
\text { facilitator }\end{array}$} & Promotional activities & $(+/ 0)$ \\
\hline & & & $\begin{array}{l}\text { Information updates on } \\
\text { availability of inputs }\end{array}$ & $(+/ 0)$ \\
\hline \multirow[t]{4}{*}{ Farmers } & \multirow{4}{*}{$\begin{array}{l}\text { The farmers are those who } \\
\text { practise farming as their } \\
\text { primary occupation. }\end{array}$} & \multirow[t]{4}{*}{ - Cultivator } & High yield & $(+)$ \\
\hline & & & $\begin{array}{l}\text { Technical and Market } \\
\text { information }\end{array}$ & $(+/-)$ \\
\hline & & & $\begin{array}{l}\text { Conservation of local rice } \\
\text { varieties }\end{array}$ & $(-)$ \\
\hline & & & $\begin{array}{l}\text { Increased income and } \\
\text { livelihood }\end{array}$ & $(+)$ \\
\hline \multirow[t]{6}{*}{ Progressive Farmer Club } & \multirow{6}{*}{$\begin{array}{l}\text { The FBO is located at } \\
\text { Nungbrung village, Imphal } \\
\text { East district. The organization } \\
\text { aims at providing assistance to } \\
\text { the fellow farmers regarding } \\
\text { best agricultural practices and } \\
\text { techniques of improving the } \\
\text { production. }\end{array}$} & \multirow{6}{*}{$\begin{array}{l}\text { Input suppliers, } \\
\text { Transfer of Technology, } \\
\text { Facilitator and } \\
\text { Coordinator }\end{array}$} & Farmer support & $(+)$ \\
\hline & & & Input Provider & $(+)$ \\
\hline & & & $\begin{array}{l}\text { Mediators for channelling } \\
\text { subsidized inputs }\end{array}$ & $(+)$ \\
\hline & & & $\begin{array}{l}\text { Promote SMART Agricultural } \\
\text { practices }\end{array}$ & $(+)$ \\
\hline & & & $\begin{array}{l}\text { Seed Production through } \\
\text { partnership }\end{array}$ & $(+)$ \\
\hline & & & Capacity Building & $(+)$ \\
\hline \multirow{6}{*}{$\begin{array}{l}\text { Langei Producer } \\
\text { Company Limited - } \\
\text { Yairipok Yambam }\end{array}$} & \multirow{6}{*}{$\begin{array}{l}\text { The FBO is located at } \\
\text { Nungbrung village, Imphal } \\
\text { East district. The organization } \\
\text { aims at providing assistance to } \\
\text { the fellow farmers regarding } \\
\text { best agricultural practices and } \\
\text { techniques of improving the } \\
\text { production. }\end{array}$} & \multirow{6}{*}{$\begin{array}{l}\text { Input suppliers, } \\
\text { - Transfer of Technology, } \\
\text { Facilitator and } \\
\text { Coordinator }\end{array}$} & Farmer support & $(+)$ \\
\hline & & & Input Provider & $(+)$ \\
\hline & & & $\begin{array}{l}\text { Mediators for channelling } \\
\text { subsidized inputs }\end{array}$ & $(+)$ \\
\hline & & & $\begin{array}{l}\text { Promote SMART Agricultural } \\
\text { practices }\end{array}$ & $(+)$ \\
\hline & & & $\begin{array}{l}\text { Seed Production through } \\
\text { partnership }\end{array}$ & $(+)$ \\
\hline & & & Capacity Building & $(+)$ \\
\hline \multirow{4}{*}{$\begin{array}{l}\text { Evergreen Vegetable } \\
\text { Centre }\end{array}$} & \multirow{4}{*}{$\begin{array}{l}\text { The FBO is located at Yairipok } \\
\text { Yambem, bordering village } \\
\text { of Imphal East and Thoubal } \\
\text { district. This organization is also } \\
\text { associated with the CAU in the } \\
\text { Participatory Seed Production } \\
\text { Innovation system for CAU-R } \\
\text { series varieties }\end{array}$} & \multirow{4}{*}{$\begin{array}{l}\text { Input suppliers, } \\
\text { Transfer of Technology, } \\
\text { Facilitator and } \\
\text { Coordinator }\end{array}$} & Increased vegetable production & $(-)$ \\
\hline & & & Marketing of vegetables & $(-)$ \\
\hline & & & Sustainable Agriculture & $(+)$ \\
\hline & & & Diversified farmer income & $(+)$ \\
\hline
\end{tabular}




\begin{tabular}{|c|c|c|c|c|}
\hline \multirow{4}{*}{$\begin{array}{l}\text { Chingarel Wangma } \\
\text { Loukol Lup }\end{array}$} & \multirow{4}{*}{$\begin{array}{l}\text { The FBO is located at Khurai } \\
\text { village Imphal East district } \\
\text { and was primarily established } \\
\text { regarding irrigation facilities in } \\
\text { the village }\end{array}$} & \multirow{4}{*}{$\begin{array}{l}\text { No role specific to } \\
\text { CAU-R series varieties }\end{array}$} & Improved irrigation facilities & $+/ 0$ \\
\hline & & & Improved Crop yield & $(+)$ \\
\hline & & & Better Market Price & $(+)$ \\
\hline & & & Capacity Building & $(+)$ \\
\hline \multirow{4}{*}{$\begin{array}{l}\text { Utlou Joint Farming } \\
\text { cum Pisciculture Co-op } \\
\text { Society Limited }\end{array}$} & \multirow{4}{*}{$\begin{array}{l}\text { The major objective of the } \\
\text { organization is the upliftment } \\
\text { of the rural society, optimum } \\
\text { utilization of local resources }\end{array}$} & \multirow{4}{*}{$\begin{array}{l}\text { Transfer of } \\
\text { Technology, Facilitator, } \\
\text { Coordinator }\end{array}$} & More focus on fishing activities & $(-)$ \\
\hline & & & Rice cum fish cultivation & $(+/ 0)$ \\
\hline & & & Transfer of technology & $(+)$ \\
\hline & & & $\begin{array}{l}\text { Livelihood and social status of } \\
\text { farmers }\end{array}$ & $(+)$ \\
\hline \multirow[t]{5}{*}{ Meira Paibi } & \multirow{5}{*}{$\begin{array}{l}\text { Meira Paibi is a women } \\
\text { based organisation function- } \\
\text { ing all over Manipur. The } \\
\text { major objective is promoting } \\
\text { women's participation in } \\
\text { economic, social and political } \\
\text { spheres of daily life. }\end{array}$} & \multirow{5}{*}{$\begin{array}{l}\text { No role specific to } \\
\text { CAU-R series varieties }\end{array}$} & Women torchbearers & $(0)$ \\
\hline & & & Societal Peace & $(0)$ \\
\hline & & & Capacity Building & $(+/ 0)$ \\
\hline & & & Food Security & $(+)$ \\
\hline & & & Improved livelihood & $(+)$ \\
\hline
\end{tabular}

Legend: $(+)=$ positive; $(-)=$ negative; (?)= not known; $(+/-)=$ positive but can be negative; (?/+)= not known but will be positive if implemented; $(? /-)=$ not known but will be negative if implemented.

activities. The stakeholders under this category were the Central Agricultural University (CAU), and the Pandit Deen Dayal Upadhyay Institute of Agriculture Sciences, Bishnupur (Shaijumon, 2014). The Research organizations included the Indian Council of Agricultural Research (ICAR) for NEH Region, Manipur Centre and the Regional Rice Research Station, Thoubal. The extension organizations included the Krishi Vigyan Kendras whose primary objective was to transfer technology and conduct vocational trainings to the farmers (Medhi et al. 2017). The Mass Media included the All India Radio, Doordarshan Kendra Imphal and the local newspaper The Sangai Express. The media plays a very important and crucial role in agricultural development of a region by promoting awareness and broadcasting news on latest and advanced technologies in agriculture (Halakatti et al. 2019).

\section{Farmers and farmer based collectives}

The farmers and farmer based collectives were identified as major stakeholders whose primary objective was to work for the socio-economic development of the farmers and the rural society. Often we fail to realise them as important stakeholders and overlook their perspective and opinions due to which many innovations though very useful have failed to be adopted by the farmers (Wennink et al. 2007). In the present study six farmer based organizations were identified in the three districts.

\section{Civil society organizations}

Under the Civil society organizations, Meira Paibi a women based organisation functioning all over Manipur has been identified as an important stakeholder. They are also known as "Women Torchbearers" and "guardians of civil society". (Aribam 2016).

\section{(II) Timeline of Stakeholders in Diffusion of CAU-R series varieties}

The importance of timeline is to identify which stakeholder has entered into the innovation system, at what stage and how their presence has influenced the system. Also the credibility and performance of the stakeholder can be accessed from the period of experience of the stakeholder in the society. In the present study timeline of all the stakeholders has been represented in the Fig. 1.

From the Fig. 1, it can be inferred that the stakeholders on the line were the active stakeholders involved directly in the popularisation and diffusion of CAU-R series varieties in Manipur. They were the CAU and KVK, Imphal East that initiated the programme in 2009 followed by farmers who were distributed with seeds of the CAU-R1 in 2009. In the year 2010, the Department of Agriculture, Manipur and KVK, Thoubal started participating in the popularization and diffusion of CAU-R1 variety. Apart from these, were the farmers and the Progressive Farmers Club, Imphal East took up the participatory seed production programme of CAU. 
The All India Radio and the Doordarshan Television channel were contacted in 2010 for advertising about the CAU-R1 variety among the farmers.

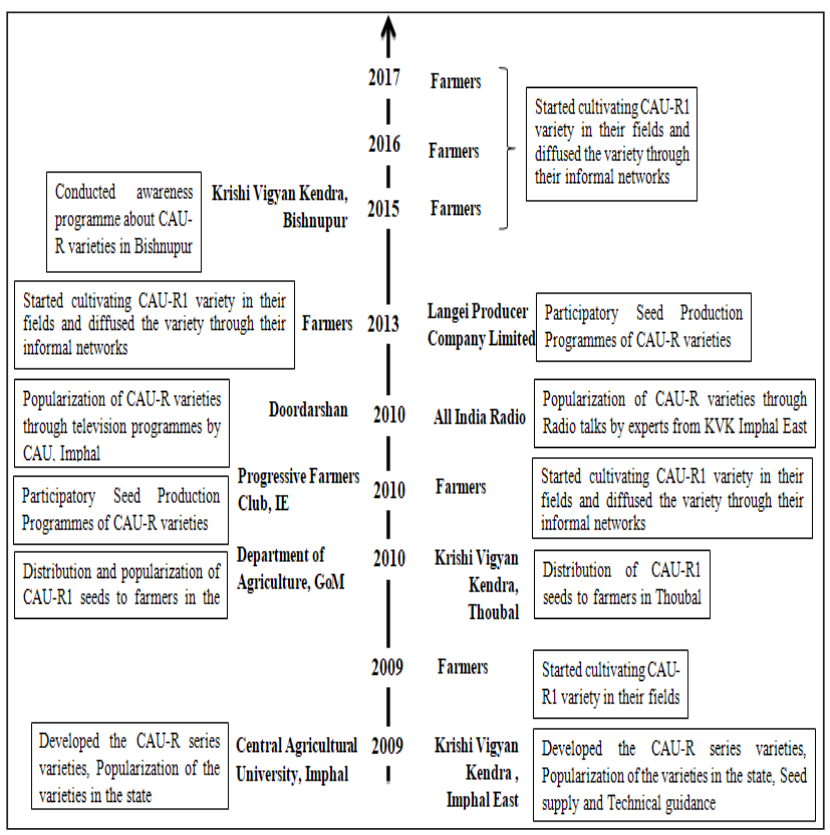

Fig. 1: Timeline representing the stakeholders
In 2013, the Langei Producer Company Limited and the farmers associated with the organization started cultivating the CAU-R1 variety in their village. During the year 2015, the KVK Bishnupur in collaboration with the CAU has organized a programme for awareness and popularization of CAU-R varieties among the farmers of Bishnupur district. The stakeholders off the line in green colour are the ones who are not involved in the system but have varying degrees of interest in the innovation system and can be considered as important actors for the future extension activities. They are the Regional Rice Research Station, Thoubal, Utlou Joint Farming cum Pisciculture Co-op Society Limited, ICAR-RC Manipur, KVK Imphal West, Sangai Express (Local newspaper), Meira Paibi, Chingarel Wangma Loukol Lup, Evergreen Vegetable Centre and Pandit Deen Dayal Upadhyay Institute of Agricultural Sciences, Bishnupur.

\section{(III) Stakeholder Power and Interest Analysis}

The power and interests of the stakeholders were documented while data collection. Power of the

Table 2: Stakeholders interest in diffusion of CAU-R series varieties

\begin{tabular}{|c|c|}
\hline Common Interests & Stakeholders \\
\hline $\begin{array}{l}\text { Increased agricultural production and productivity of } \\
\text { the State }\end{array}$ & $\begin{array}{l}\text { - Ministry of Agriculture and Farmers Welfare, Department of Agriculture, } \\
\text { - Government of Manipur, } \\
\text { - Central Agricultural University, Imphal } \\
\text { - KVAR-NEH, RC Manipur } \\
\text { - Imphal East, Thoubal and Bishnupur) }\end{array}$ \\
\hline Develop High Yielding Varieties of Rice & $\begin{array}{l}\text { - Department of Agriculture, Government of Manipur, } \\
\text { - Central Agricultural University, Imphal } \\
\text { - } \text { ICAR-NEH, RC Manipur } \\
\text { - Regional Rice Research Station }\end{array}$ \\
\hline Socio-economic condition of the farmers & $\begin{array}{l}\text { - Department of Agriculture, Government of Manipur, } \\
\text { - Central Agricultural University, Imphal } \\
\text { - ICAR-NEH, RC Manipur } \\
\text { - KVKs (Imphal East, Thoubal and Bishnupur) } \\
\text { - Farmers } \\
\text { - Farmer based organizations }\end{array}$ \\
\hline $\begin{array}{l}\text { Popularization of advanced and improved } \\
\text { technologies }\end{array}$ & $\begin{array}{l}\text { - Department of Agriculture, Government of Manipur, } \\
\text { - } \text { Central Agricultural University, Imphal } \\
\text { - KVKs (Imphal East, Thoubal and Bishnupur) } \\
\text { - All India Radio, Imphal } \\
\text { - Doordarshan Television, Imphal } \\
\text { - Sangai Newspaper }\end{array}$ \\
\hline
\end{tabular}




\begin{tabular}{|c|c|}
\hline $\begin{array}{l}\text { Provide adequate and timely technical advice on } \\
\text { inputs and diagnostic services specific to CAU-R } \\
\text { series varieties to the farmers }\end{array}$ & $\begin{array}{l}\text { - Department of Agriculture, Government of Manipur, } \\
\text { - Central Agricultural University, Imphal } \\
\text { - KVK Imphal East } \\
\text { - KVK Thoubal }\end{array}$ \\
\hline $\begin{array}{l}\text { Rewards and Recognition in terms of institution } \\
\text { ranking, best technology awards, financial grants, } \\
\text { best innovative farmer awards etc. }\end{array}$ & $\begin{array}{l}\text { - Department of Agriculture, Government of Manipur, } \\
\text { - KVntral Agricultural University, Imphal } \\
\text { - KVK Thphal East } \\
\text { - Farmers }\end{array}$ \\
\hline
\end{tabular}

\section{Conflictive Interests}

\begin{tabular}{|l|l|}
\hline Stakeholders (with interest) & Stakeholders (with interest) \\
\hline $\begin{array}{l}\text { - ICAR and KVK, Imphal West wants to continue with the } \\
\text { popularization of ICAR- RCM HYVs of Rice in the State }\end{array}$ & $\begin{array}{l}\text { CAU and KVK Imphal East want more wide spread popularization } \\
\text { of CAU-R series varieties of Rice }\end{array}$ \\
\hline $\begin{array}{l}\text { CAU, ICAR and Department of Agriculture wants farmers to } \\
\text { adopt HYVs }\end{array}$ & $\begin{array}{l}\text { Many farmers want to cultivate local varieties as the HYVs are } \\
\text { perceived as not so tasty compared to the HYVs }\end{array}$ \\
\hline
\end{tabular}

stakeholders in the innovation system was assessed by power attributes describing the power to allocate or deny resources, defining others tasks and responsibilities, controlling access to knowledge or information, decision making and channelling messages to other stakeholders (Kennon et al. 2009). The interest of the stakeholders in the innovation system were categorised into common interest and conflictive interests. This was done to identify the stakeholder group having common interest in the diffusion of CAU-R series varieties so as to formulate strategies to strengthen their relationship while the stakeholder groups with conflictive interests were identified to understand and plan for resolving the conflicts which if not may hamper the innovation system.

The vested interest of the stakeholders was documented during the interview of the respondents and classified as common interests and conflictive interests. The common interests of the stakeholders were increased agricultural production and productivity of the state, developing high yielding varieties of rice, improve the socioeconomic condition of the farmers, popularization of advanced and improved technologies among the farmers, provide adequate and timely technical advice on inputs and diagnostic services specific to CAU-R series varieties to the farmers, recognition and rewards in the form of institution rankings, best technology awards, financial grants, Best farmer and Innovative Farmer Awards. The CAU, DoA, MoAF, ICAR-RC, Manipur, KVK (Thoubal, Imphal East and Bishnupur), All India Radio, Television and Sangai newspaper were the stakeholders with common interests. However, the conflictive interests were found in between the CAU and the ICAR-RC, Manipur, reason being that the ICAR-RC, Manipur has developed series of RCM varieties of Rice and extensively popularized them among the farmers. Hence their interest in CAU-R series varieties was contradictory. Similarly a few farmers were reluctant to cultivate the HYV's of Rice owing to tastier local variety than the CAU-R series varieties.

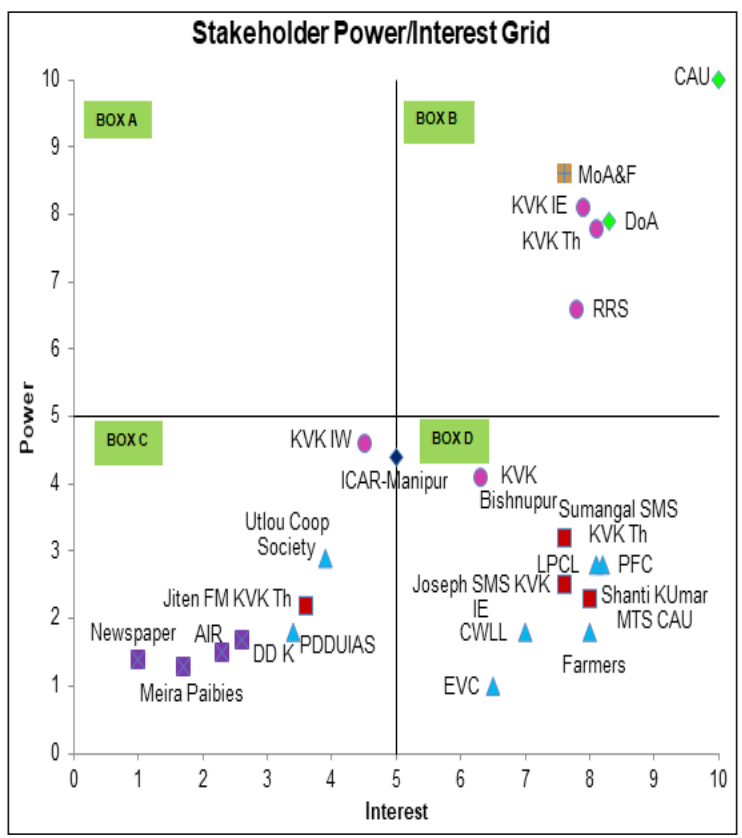

Fig. 2: Stakeholder Power/Interest Grid

On perusal with Table 4 and Fig. 2 we can distinguish the position of the stakeholders with regard to Power and Interest on a 10 point continuum. 
The perceptions and responses were collected from the key personnel working in the Central Agricultural University, College of Agriculture, Iroisemba, KVK Imphal East and KVK Thoubal since these are the key organizations involved fully in the popularization and diffusion of the CAU-R series varieties in Manipur. The total number of respondents considered for the Power/Interest Matrix was 14 . The mean scores of the all the 14 respondents was calculated and based on these values the power/interest grid was prepared. The results revealed that the respondents perceived the CAU, the Ministry of Agriculture and Farmers Welfare and the Department of Agriculture, Government of Manipur had high degree of power and interest in all the three districts while the ICARNEH, RC Manipur and KVK, Imphal West have neutral power and interest reason being as stated above they have their own Rice varieties namely RCM series which they are popularising among the farmers.

Table 3: Mean Scores of the Power and Interests of the Stakeholders in diffusion of CAU-R series varieties in Manipur

\begin{tabular}{|c|c|c|}
\hline Stakeholder & $\begin{array}{l}\text { Power } \\
\text { (Mean } \\
\text { Score) }\end{array}$ & $\begin{array}{c}\text { Interest (Mean } \\
\text { Score) }\end{array}$ \\
\hline MoA\&F & 8.6 & 7.6 \\
\hline CAU & 10.0 & 10.0 \\
\hline DoA & 7.9 & 8.3 \\
\hline ICAR-RC Manipur & 4.4 & 5.0 \\
\hline KVK Imphal East & 8.1 & 7.9 \\
\hline KVK Imphal West & 4.6 & 4.5 \\
\hline AIR & 1.5 & 2.3 \\
\hline DD K & 1.7 & 2.6 \\
\hline Newspaper & 1.4 & 1.0 \\
\hline LPCL & 2.8 & 8.2 \\
\hline PFC & 2.8 & 8.1 \\
\hline CWLL & 1.8 & 7.0 \\
\hline Joseph SMS KVK Imphal East & 2.5 & 7.6 \\
\hline Meira Paibies & 1.3 & 1.7 \\
\hline Farmers & 1.8 & 8.0 \\
\hline KVK Th & 7.8 & 8.1 \\
\hline RRS & 6.6 & 7.8 \\
\hline Sumangal SMS KVK Th & 3.2 & 7.6 \\
\hline Jiten FM KVK Th & 2.2 & 3.6 \\
\hline Evergreen Vegetable Centre & 1.0 & 6.5 \\
\hline KVK Bishnupur & 4.1 & 6.3 \\
\hline
\end{tabular}

\begin{tabular}{lll} 
PDDUIAS & 1.8 & 3.4 \\
Utlou Joint Farming & 2.9 & 3.9 \\
Shanti Kumar MTS CAU & 2.3 & 8.0 \\
\hline
\end{tabular}

Table 4: Interpretation of the Stakeholder prioritization matrix

\begin{tabular}{|l|l|l|}
\hline Box & Interpretation & Suggestions \\
\hline Box A & $\begin{array}{l}\text { High Power to influence but } \\
\text { low interest in the innovation } \\
\text { system }\end{array}$ & $\begin{array}{l}\text { Need special initiative, } \\
\text { by concerned authorities } \\
\text { tosafeguard their interest }\end{array}$ \\
\hline Box B & $\begin{array}{l}\text { High Power to influence and } \\
\text { high interest in the innovation } \\
\text { system }\end{array}$ & $\begin{array}{l}\text { Very important category } \\
\text { and strong relationship } \\
\text { needs to be maintained } \\
\text { among these stakeholders }\end{array}$ \\
\hline Box C & $\begin{array}{l}\text { Low Power as well as interest } \\
\text { in the innovation system }\end{array}$ & $\begin{array}{l}\text { Not so important but } \\
\text { need to monitored } \\
\text { regularly and evaluated }\end{array}$ \\
\hline Box D & $\begin{array}{l}\text { Have high interest in the } \\
\text { innovation system capable of } \\
\text { bringing desirable outcomes } \\
\text { but with limited power to take } \\
\text { decisions }\end{array}$ & $\begin{array}{l}\text { Need careful monitoring } \\
\text { and evaluation }\end{array}$ \\
\hline
\end{tabular}

Also in all the three districts, the media i.e., All India Radio, Doordarshan, Newspaper and Meira Paibies had low interest and power. Farmers in all the three districts have shown high level of interest in the diffusion of CAU-R series varieties owing to its high production compared to other HYVs cultivated but their degree of power to implement or change any unfavourable regulation is highly limited. According to the suggestions given in Table 4 it is advisable to include farmers in the diffusion of CAU-R series varieties, regular monitoring of the crop performance at their fields, provision of required inputs on a timely basis, feedback of the crop and most importantly provide for market linkages to improve their economic stature. Also the Farmer based organization i.e., Progressive Farmers Club and Langei Producer Company Limited which are at present actively involved in the innovation system also need careful monitoring and their feedback given due consideration. The Krishi Vigyan Kendras in Imphal East and Thoubal are working sincerely for the innovation system while the Krishi Vigyan Kendra Bishnupur has interest but not involved full flegedly in the innovation system. If this KVK along with its host institute Utlou Joint Farming cum Pisciculture Co-op Society Limited and Pandit Deen Dayal Upadhyay Institute of Agriculture Sciences can be considered as important stakeholders in Bishnupur district. The results were 
in partial similarity with the study conducted by Ponkka (2017).

\section{CONCLUSION}

The observations and results obtained in this study reveals that among the institutional stakeholders the Central Agricultural University has the ultimate power and authority followed by the Department of Agriculture, Government of Manipur. This study will serve as a roadmap to the host institute the Central Agricultural University in engaging the important stakeholders for their future research projects. Participatory mode of research involving all the stakeholders at the relevant stages of the innovation system will give more focussed and desired results.

\section{ACKNOWLEDGEMENTS}

I would like to express my deep gratitude to the ICAR for providing me financial assistance in the form of SRF Scholarship and the Central Agricultural University, Imphal for allowing me to work on this topic.

\section{REFERENCES}

Annual Report 2017-18. 2017. Department of Agriculture, Cooperation \& Farmers Welfare. Ministry of Agriculture \& Farmers Welfare.

Badibanga, T., Ragasa, C. and Ulimwengu, J. 2013. Assessing the effectiveness of multi stakeholder platforms: agricultural and rural management councils in the Democratic Republic of the Congo. doi:10.1007/s12571016-0595-5

Barzola, C., Dentoni, D., Mordini, M., Isubikalu, P., Beatrice, A.O. and Judith, O.O. 2019. The Role of Farmers' Entrepreneurial Orientation on Agricultural Innovations in Ugandan Multi-Stakeholder Platform: Investigating the Business of a Productive, Resilient and Low Emission Future. doi: 10.1007/978-3-319-92798-5_17

CAU Farm Magazine, Vol 7, No.4

https://www.cau.ac.in/file/Farm\%20Magazines/CAU\%20 Farm \%20Magazine \%20Vol\%207\%20No.\%204.pdf Accessed on 24 Feb 2019

Dentoni, D. and Peterson, H.C. 2011. Multi-stakeholder sustainability alliances in agri-food chains: A framework for multi-disciplinary research. Int. Food Agribus. Manag. Rev., 14(5): 83-108.

Government of Manipur. 2015. http://www.manenvis.nic.in/ Database/Agriculture_2720.aspx Accessed on 21 Feb 2019

Halakatti, S.V., Gowda, D.S.M. and Natikar, K.V. 2010. Role of mass media in transfer of agricultural technologies. Res. J. Agric. Sci., 1: 290-291.
Kennon, N., Howden, P. and Hartley, M. 2009. Who Really Matters? A Stakeholder Analysis Tool. Ext. Farming Syst. J., 5(2): 9-17.

MacArthur, J.D. 1997. Stakeholder Roles and Stakeholder Analysis in Project Planning: A review of approaches in three agencies - World Bank, ODA and NRI. Bradford: University of Bradford, Development and Project Planning Centre. doi: 10.1080/02688867.1997.9727068

Martey, E., Etwire, P.M., Wiredu, A.N. and Dogbe, W. 2014. Factors influencing willingness to participate in Multistakeholder platform by smallholder farmers in Northern Ghana: implication for research and development. Agric. Food Econ., 2(1): 1.

Medhabati, K., Das, R.K., Rohinikumar, M., Sunitibala, H. and Thingbaijam, D.S. 2013. Genetic Divergence in Indigenous Wild and Cultivated Rice Species of Manipur Valley. Hindawi Publishing Corporation. ISRN Genetics doi: 10.5402/2013/651019

Arabam, K. 2016. Meirapaibi https://kapilarambam.blogspot. com/2016/02/meira-paibi-brief-story-of-women-torch. html Accessed on 29 Jan 2019

ODA. 1995. Guidance Note on How to do a Stakeholder Analysis of Aid Projects and Innovation Systems. London. Overseas Development Administration, Social Development Department doi: 10.30541/v35i2pp.189-190

Ponnka, P. 2017. Exploring Potential Stakeholders in the Organic Business Field in Nepal. Dissertation International Business.

Russo, A. and Tencati, A. 2009. Formal vs. informal CSR strategies: Evidence from Italian micro, small, mediumsized, and large firms. J. Bus. Eth., 85(2): 339-353.

Shaijumon. 2014. Institutions and technology diffusion in agriculture: Role of ISRO Village Resource Centers. Eur. Sci. J., 10(10): 480-497.

Singh, K.J., Feroze, S.M., Singh, R., Saravanan, R. and Singh, N.U. 2016. How profitable is Rice cultivation in Manipur: An economic appraisal. Agrarian Economy in India First Edition, pp. 59-66.

Sarkar, S., Tabassum, T. and Sadashivam (Eds), Manglam Publication, Delhi. doi: 10.5958/0976-4666.2016.00042.5

Thongbam, P.D., Durai, A., Anna, Singh, Anand, T., Devi, B., Gupta, S., Mitra, J., Pattanayak, A., Dhiman, K.R., Bhadana, V.P., Hore, D.K. and Ngachan, S.V. 2010. Grain and food quality traits of some indigenous medicinal rice cultivars of Manipur. Int. J. Food Prop., 13(6): 1244-1255.

Wennink, B., Nederlof, S. and Heemskerk, W. 2007. Access of the Poor to Agricultural Services: The Role of Farmers' Organizations in Social Inclusion, Bulletin 376, Published by The Royal Tropical Institute (KIT), Amsterdam, 2007, ISBN 9789068326420, 160 pp., paperback, [euro] 25.00.doi: $10.1080 / 13892240802416277$. 